\title{
THE COLONIAL INSTITUTE.
}

THE following letter was read at the Annual General Meeting of the Society held on February 17, 1887, and was then ordered to be printed in the Society's Transactions :-

\author{
Offices of the Imperial Institute, \\ I Adam Street, Adelphi : February 4, 1887.
}

Sir,-I have received the instructions of his Royal Highness the Prince of Wales to submit to you the request that you will be so good as to inform the Council of the Royal Historical Society of the hope entertained by his Royal Highness that they will feel disposed to invite the Fellows of the Society to take part in the foundation of the Imperial Institute for the United Kingdom, the Colonies, and India which is being established in commemoration of the fiftieth anniversary of the Queen's reign.

The Prince of Wales believes that the form which it has been decided to give to this national memorial, and which has met with her Majesty's gracious approval, is of a nature especially to commend itself to the Fellows of the Society, inasmuch as the objects aimed at, and which it is hoped to attain by the creation of the Imperial Institute, are, in several important respects, kindred to, or in harmony and sympathy with, the important functions of the Society of which you are President.

If you and your Council should be willing to make an appeal to the Fellows of your Society to transmit through the Society their donations towards the fund required for the establishment of the Imperial Institute, the Society will thereby become directly identified with this national manifestion of the respect and affection entertained for her Majesty by all classes of her subjects.

I beg leave to enclose a pamphlet descriptive of the nature and objects of the Institute, and shall be glad to give directions for the transmission to the Society of this and other papers for distribution among the Fellows, should the suggestion of his Royal Highness be favourably entertained by yourself and your Council.

I have the honour to be, Sir,

Your obedient Servant,

The President of the Royal Historical Society, \&c.

\author{
F. A. ABEI, \\ Organising Secretary.
}

